\title{
Effects of Pseudomonas fluorescens Seed Bioinoculation on Heavy Metal Accumulation for Mirabilis jalapa Phytoextraction in Smelter-Contaminated Soil
}

\author{
M. Petriccione - D. Di Patre • P. Ferrante - S. Papa • \\ G. Bartoli • A. Fioretto • M. Scortichini
}

Received: 3 February 2013 / Accepted: 3 July 2013

(C) Springer Science+Business Media Dordrecht 2013

\begin{abstract}
Some Pseudomonas fluorescens strains, consistently isolated from the rhizosphere of wild plants grown in a soil that was highly polluted with illegal waste of smelter residues, were utilised for Mirabilis jalapa seed bioinoculation to verify their effects on seed germination and on promoting a higher heavy metal accumulation in the plant rhizosphere and/or uptake in the leaves. The high content of heavy metals in the soil induced a decrease in either the leaf dry weight or photosynthetic pigment concentration during all vegetative phase of $M$. jalapa. Bioinoculation with $P$. fluorescens strains significantly increased the germination of seeds and the root length in the contaminated soil. In some bacterial strain/seed combination, bioinoculation significantly increased the accumulation of heavy metals in $M$. jalapa rhizosphere. For $\mathrm{Cd}$, the concentration of this metal in the rhizospheres of bioinoculated plants ranged from 270 to $910 \mathrm{\mu g} \mathrm{g}^{-1}$ of
\end{abstract}

\footnotetext{
M. Petriccione $(\varangle) \cdot$ D. Di Patre $\cdot$ M. Scortichini Consiglio per la Ricerca e la Sperimentazione in Agricoltura - Fruit Trees Unit Research,

Via Torrino 3, 81100 Caserta, Italy

e-mail: milena.petriccione@entecra.it

P. Ferrante

Consiglio per la Ricerca e la Sperimentazione in Agricoltura - Fruit Crops Research Centre,

Via di Fioranello 52, 00134 Roma, Italy

S. Papa $\cdot$ G. Bartoli $\cdot$ A. Fioretto

Life Science Department, Second University of Naples,

Via Vivaldi 43, 81100 Caserta, Italy
}

dry weight compared with $200 \mu \mathrm{g} \mathrm{g}^{-1}$ of dry weight for the non-coated plants. Two P. fluorescens strains, AA27 and MO49, which were isolated from Artemisia annua and Melilotus officinalis, respectively, induced a significantly higher rhizosphere availability also for $\mathrm{Cr}, \mathrm{Cu}$, $\mathrm{Ni}$ and $\mathrm{Zn}$. However, despite the relevant accumulation of the heavy metals in the plant rhizosphere, generally the metal uptake into the leaves was rather low. Both analysis of variance and principal component analysis confirmed this finding. However, one P. fluorescens strain, CD1, which was isolated from the multi-metal accumulator Cynodon dactylon, significantly promoted the M. jalapa leaf uptake for $\mathrm{Cr}, \mathrm{Cu}$ and $\mathrm{Zn}$. The plant metal uptake assessment, confirmed the per se capability of M. jalapa to effectively uptake $\mathrm{Cd}(30 \%)$ and $\mathrm{Cu}$ $(12.72 \%)$ from the rhizosphere to the leaves, whereas the uptake for the other metals was low: $\mathrm{Ni}(2.66 \%), \mathrm{Zn}$ (2.46 \%), $\mathrm{Cr}(1.75 \%), \mathrm{Pb}(0.73 \%)$.

Keywords Bacteria-assisted phytoremediation · Soil pollution · PGPR · Fluorescent pseudomonads . Hyperaccumulator plants

\section{Introduction}

The contamination of soil by the release of refuses containing hazardous compounds such as heavy metals is a relevant environmental problem worldwide that increases human health risks, water contamination, soil erosion, phytotoxicity and ecotoxicity. When the pollutants reach 
agricultural soil, the contamination can dramatically limit the marketing of the crops thus reducing profitability ( $\mathrm{Mc}$ Grath et al. 2001). Contamination with heavy metals can result from mining, industrial and military practices. In addition, illegal waste dumps of toxic slugs containing heavy metals can contribute to this problem. Commonly used cleanup methods involve the excavation and landfilling of the contaminated soil. The chemical cleaning of polluted agricultural soils is costly and for many pollutants, no low-cost technologies are available for reducing the level of contamination.

In contrast, bioremediation is a relatively new and emerging technology that utilises the possibility of the in situ attenuation/elimination/transformation of hazardous materials using particular biological processes. Among these, plant-assisted bioremediation, better known as phytoremediation (i.e., the use of some plant species for reducing the content of pollutants in chemically and/or radioactively contaminated soils), has shown good results (Wenzel 2009). Among the technologies currently used in phytoremediation, phytoextraction (i.e., a process utilising the unusual capability of some plant species to accumulate metals in their leaves and/or shoot) and rhizodegradation (i.e., the metabolic capability of a plant and its rhizosphere to degrade pollutants), and their combination (Sriprang and Murooka 2007), can greatly contribute to restoring the fertility of contaminated soils. The effectiveness of phytoremediation primarily depends on plant growth and a high heavy metal concentration in the above-ground organs of the plant.

Within this context, bacteria, including plantgrowth-promoting-rhizobacteria (PGPR), can enhance the effectiveness of rhizodegradation by increasing pollutant availability for possible plant uptake (PU) (Zhuang et al. 2007; Khan et al. 2009; Glick 2010; De Bashan et al. 2012). In fact, bacteria have the capacity to increase plant growth under adverse conditions and promote heavy metal solubility through various mechanisms such as the production of organic ligands, exudation of organic acids and complexation of cationic metals or desorption of anionic species via ligand exchange by siderophores (Gadd 2004). Among PGPR species, fluorescent pseudomonads are frequently recovered from both the soil and plant rhizospheres. Among these, Pseudomonas fluorescens is a well-known soil and rhizosphere inhabitant (Van Elsas et al. 2006) that can tolerate high concentrations of heavy metals in polluted waters (Wasi et al. 2010). Its utilisation as a seed bioinoculant for hyperaccumulator plants is currently unknown, and there are very few studies aimed at investigating its capability for increasing the metal availability of the rhizospheres of such plants (Dell'Amico et al. 2008; Sheng et al. 2008). Even though PGPR have a major potential in bioremediation, studies devoted to microorganisms assisted plants for metal extraction from soil should be augmented (Lebeau et al. 2008; De Bashan et al. 2012). Within this context, a better understanding of the influence of $P$. fluorescens in promoting the heavy metal availability of hyperaccumulator plants is a critical prerequisite for its possible utilisation in bacteriaassisted phytoremediation.

Mirabilis jalapa L. (four o'clock, marvel of Perù) is a plant species from tropical South America that is utilised as an ornamental plant in Europe, Asia and America. It is also well known for its rapid growth and metal hyperaccumulation properties (Kambhampati and Williams 2001; Cao et al. 2007; Yu and Zhou 2009; Sun et al. 2011). Hyperaccumulation of heavy metals by some terrestrial plants has been extensively investigated. In contrast, considerably less information is available on the processes that occur in the rhizospheres of hyperaccumulators. An effective root uptake mechanism for heavy metals is among the key processes in the rhizosphere that distinguish metal hyperaccumulators from normal plants. Accumulation of knowledge on the interactions between hyperaccumulator plants and beneficial rhizosphere microorganisms will enhance biomass production and the tolerance of the plants to heavy metals, and is considered to be an important component of phytoremediation technologies (Dzantor 2007; Wenzel 2009).

The main aims of this study were as follows: (1) to select plant growth promoting isolates of $P$. fluorescens from rhizospheric soil samples highly contaminated with heavy metals; (2) to check the effects of a high heavy metal soil content on M. jalapa growth; (3) to putatively assess the capability of $M$. jalapa rhizosphere to increase heavy metal accumulation (i.e., $\mathrm{Cd}$, $\mathrm{Cr}, \mathrm{Cu}, \mathrm{Ni}, \mathrm{Pb}, \mathrm{Zn}$ ) and their uptake from a smeltercontaminated soil into the plant leaves; and (4) to verify the influence of coating $M$. jalapa seeds with $P$. fluorescens strains isolated from the rhizosphere of other plants on the phytoremediation activity of this hyperaccumulator plant. 


\section{Materials and Methods}

\subsection{Soil Sampling and Characterisation}

Soil samples were collected in Santa Maria la Fossa, Portillo (Caserta province, southern Italy). The private soil, which was not utilised for agricultural crop production, was contaminated by an illegal dump several years before this study when waste residues taken from an unknown smelter were spread on the soil. Twenty samples were randomly taken from different sites within this area by collecting soil from a range of $0-40 \mathrm{~cm}$ in depth. The soil contained a relevant number of spherical, metalloid residues of different sizes (i.e., $1.5-4 \mathrm{~cm}$ in diameter) from the smelter which were very frequently found within the sampled soil depth (Fig. 1). The total soil sample (about $300 \mathrm{~kg}$ ) was transported to the laboratory and subsequently used to prepare the pot experiment with $M$. jalapa. The soil was characterised by physical and chemical analysis according to the Italian Official Methods of soil chemical analysis (Ministry of Agricultural, Food and Forestry Policies 1999) for its heavy metal concentration by following previously described procedures for rhizosphere and leaf analysis (Papa et al. 2010; Bartoli et al. 2012). The analyses were repeated three times. The texture and physical-chemical parameters of the smelter-contaminated soil and its heavy metal content are reported in Tables 1 and 2, respectively. The control soil was taken from a non-contaminated (i.e., the presence of heavy metals was within the law limits) farm

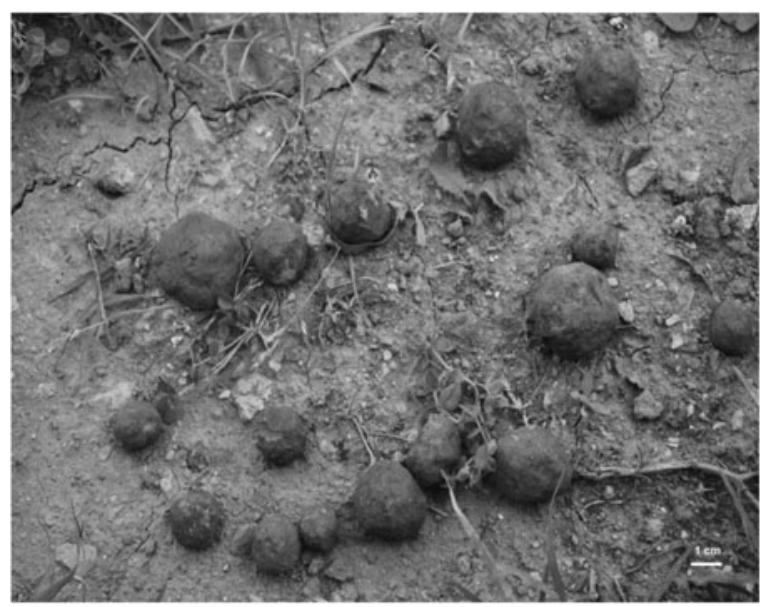

Fig. 1 Spherical, metalloid smelter residues $(1.5-4 \mathrm{~cm}$ in diameter) found few centimeters below the soil level. The presence of such residues was very relevant in the sampled area
Table 1 Values $(n=3)$ of texture, selected physico-chemical and chemical parameters of the smelter contaminated soil taken at $\mathrm{S}$. Maria la Fossa-Portillo (Caserta province, southern Italy)

Parameter

\begin{tabular}{|c|c|}
\hline Sand $(\%)$ & 63 \\
\hline Silt (\%) & 24 \\
\hline Clay $(\%)$ & 13 \\
\hline Texture & Loam-sandy \\
\hline $\mathrm{pH}$ & 7.8 \\
\hline Conductivity $\left(\mathrm{dS} \mathrm{m}^{-1}\right)$ & 0.48 \\
\hline Organic carbon $(\%)$ & 3.14 \\
\hline Total nitrogen $(\%)$ & 0.168 \\
\hline Available P (mg kg ${ }^{-1}$ d.w.) & 20 \\
\hline Total K (mg kg ${ }^{-1}$ d.w.) & 239 \\
\hline Total Ca $(\%)$ & 14.0 \\
\hline Total Mg (g kg ${ }^{-1}$ d.w.) & 576 \\
\hline Total Na ( $\mathrm{g} \mathrm{kg}^{-1}$ d.w. $)$ & 71 \\
\hline Total B ( $\mathrm{g} \mathrm{kg}^{-1}$ d.w.) & 1.94 \\
\hline Cation exchange capacity $\left(\operatorname{cmol}(+) \mathrm{kg}^{-1}\right.$ d.w. $)$ & 13.72 \\
\hline Ex. $\mathrm{Na}\left(\mathrm{cmol}(+) \mathrm{kg}^{-1}\right.$ d.w. $)$ & 0.31 \\
\hline Ex. K (cmol(+) $\mathrm{kg}^{-1}$ d.w. $)$ & 0.61 \\
\hline Ex. $\mathrm{Mg}\left(\mathrm{cmol}(+) \mathrm{kg}^{-1}\right.$ d.w. $)$ & 4.80 \\
\hline Ex. Ca (cmol(+) $\mathrm{kg}^{-1}$ d.w. $)$ & 8.00 \\
\hline
\end{tabular}

The soil was analysed according to the Italian official methods of soil chemical analysis

d.w. dry weight, ex exchangeable

located in the Caserta province and analysed in the same manner as the contaminated soil. The main

Table 2 Mean concentration ( $\mathrm{mg} \mathrm{kg}^{-1}$ d.w.) and standard deviation of selected heavy metals revealed in the smeltercontaminated soil taken at S. Maria la Fossa-Portillo (Caserta province, southern Italy)

\begin{tabular}{lccr}
\hline Metal & \multirow{2}{*}{$\begin{array}{c}\text { Concentration } \\
\left(\mathrm{mg} \mathrm{kg}^{-1} \text { d.w. }\right)\end{array}$} & \multicolumn{2}{l}{ Italian law limits } \\
\cline { 3 - 4 } & & $\mathrm{A}$ & $\mathrm{B}$ \\
\hline $\mathrm{Cd}$ & $63.5 \pm 8.2$ & 2 & 15 \\
$\mathrm{Cr}$ & $179 \pm 63.2$ & 150 & 800 \\
$\mathrm{Cu}$ & $197.5 \pm 17.7$ & 120 & 600 \\
$\mathrm{Ni}$ & $46 \pm 2.8$ & 120 & 500 \\
$\mathrm{~Pb}$ & $3,330 \pm 139.7$ & 100 & 1,000 \\
$\mathrm{Zn}$ & $16,300 \pm 2,701.2$ & 150 & 1,500 \\
\hline
\end{tabular}

The concentration of each element was measured by atomic adsorption spectrometry. The heavy metals law limits according to the Italian Legislation Decree no. 152/2006, for public gardening/private utilization (A) and for commercial/industrial (B) soils, are also indicated 
characteristics of the control soil were as follows: $68 \%$ sand, $25 \%$ silt, $7 \%$ clay (i.e., loamy-sandy texture); pH 7.8; $18 \%$ total calcium, $3.9 \%$ organic matter.

\subsection{Isolation of Fluorescent Pseudomonads from the Rhizospheres of Wild Flora}

Surveys on the area allowed us to ascertain the presence of wild flora grown on the polluted soil. Common species included Artemisia annua, Conyza canadensis, Cynodon dactylon and Melilotus officinalis. These species were identified by a botany expert, according to Pignatti (1982). Specimens of individual plants, including the root systems, were carefully collected to isolate fluorescent pseudomonads. From each species, isolations were performed using the rhizosphere, which was defined as the soil released from around the roots, including the tiny particles (1-2 mm), after gentle shaking (Angle et al. 1996). These components were placed into sterile mortars containing $5 \mathrm{ml}$ of sterile saline $(0.85 \%$ of $\mathrm{NaCl}$ in distilled water) (SS). Ten-fold serial dilutions were also made in sterile tubes. Aliquots $(0.1 \mathrm{ml})$ of the suspensions were streaked onto Petri dishes containing the medium B described by King et al. (1954) (KB). The plates were incubated at $25 \pm 1{ }^{\circ} \mathrm{C}$ for $48 \mathrm{~h}$. Then, for each plant species, representative UV fluorescent colonies were streaked in purity onto nutrient agar (NA; Oxoid, Basingstoke, UK) for their identification.

\subsection{Identification of Bacterial Isolates}

For all of the fluorescent isolates, a preliminary assessment was conducted by performing the LOPAT tests (i.e., presence of levan and cytochrome oxidase, potato soft-rot, presence of arginine dehydrolase, and tobacco leaf hypersensitivity) following the procedures described by Lelliott and Stead (1987). For the identification, isolates suspected to belong to P. fluorescens were compared with two genuine strains of the species obtained from the National Collection of Plant Pathogenic Bacteria (York, UK), NCPPB 1801 and NCPPB 1802 , which were isolated from soil, by performing repetitive sequence PCR (rep-PCR) using BOX and ERIC primer sets. This technique enables the accurate identification of bacterial isolates (Scortichini et al. 2000, 2002; Ferrante and Scortichini 2009). Briefly, for each isolate and $P$. fluorescens comparative strain, a loop full (diameter of approximately $2 \mathrm{~mm}$ ) of a single colony that had been grown for $24 \mathrm{~h}$ on NA at $25-27^{\circ} \mathrm{C}$ was suspended in SS and centrifuged at $12,000 \times \mathrm{g}$ for $2 \mathrm{~min}$. The supernatant was then discarded and the pellet was resuspended in $100 \mu \mathrm{l}$ of $0.05 \mathrm{M} \mathrm{NaOH}$ to an optical density corresponding with $1-2 \times 10^{8} \mathrm{cfu} \mathrm{ml}^{-1}$. The suspension was placed in water at $95{ }^{\circ} \mathrm{C}$ for $15 \mathrm{~min}$ and then centrifuged at $12,000 \times \mathrm{g}$ for $2 \mathrm{~min}$. Subsequently, the supernatant was stored at $-20{ }^{\circ} \mathrm{C}$ for rep-PCR analysis. The BOX and ERIC primer sets were synthesised by Primm (Milan, Italy). The rep-PCR method used was previously described by Louws et al. (1994). The PCR amplifications were performed in duplicate. PCR products were separated by electrophoresis on $1.5 \%$ agarose gels (Seakem, Rockland, ME, USA) in 0.5X TAE buffer at $5 \mathrm{~V} / \mathrm{cm}$ over $5 \mathrm{~h}$, stained with ethidium bromide, visualised and photographed under a high-resolution gel imaging system (Molecular Imager Gel Doc ${ }^{\mathrm{TM}}$ XR System; Bio-Rad, Hercules, CA, USA). In addition, all putative Pseudomonas isolates were tested for the presence of a 450-bp Pseudomonas-specific DNA band (Johnsen et al. 1999). Amplification was performed using the primer 16SF-PSMG (5'-CCTTCCTCCCAACTT-3') and the following thermal profile: $94{ }^{\circ} \mathrm{C}$ for $6 \mathrm{~min}$; 35 cycles consisting of $92{ }^{\circ} \mathrm{C}$ for $30 \mathrm{~s}, 52{ }^{\circ} \mathrm{C}$ for $30 \mathrm{~s}$, and $68^{\circ} \mathrm{C}$ for $1 \mathrm{~min}, 68^{\circ} \mathrm{C}$ for $6 \mathrm{~min}$; and final cooling at $4{ }^{\circ} \mathrm{C}$. The PCR products were stained, visualised and photographed as previously described.

\subsection{Seed Bioinoculation, Germination Assessment and Re-isolation from Potted Plants}

M. jalapa seeds were coated with four representative $P$. fluorescens strains before the sowing (i.e., one strain for each wild plant species collected in the contaminated site). Before inoculation, the seeds were surfacesterilised with a mixture of ethanol and $30 \% \mathrm{H}_{2} \mathrm{O}_{2}$ (1:1) for $15 \mathrm{~min}$ and, subsequently, washed three times for $10 \mathrm{~min}$ each with sterile distilled water. For each strain, suspensions were prepared in SS in 50-ml tubes using single 24-h-old loop colonies grown on NA, at 24-25 ${ }^{\circ} \mathrm{C}$. Bacterial cells were harvested by centrifugation at $10,000 \times g$ for $5 \mathrm{~min}$, at $4{ }^{\circ} \mathrm{C}$, and the pellet was washed two times with SS by centrifugation. The pellet was then resuspended in $20 \mathrm{ml} \mathrm{SS}$ and vortexed. The bacterial suspensions were placed into sterile 500$\mathrm{ml}$ Erlenmeyer flasks containing the appropriate volume of sterile distilled water to reach a photometrically determined concentration of $1-2 \times 10^{9} \mathrm{cfu} \mathrm{ml}^{-1}$. Then, the $M$. jalapa seeds were placed into the suspension 
and incubated at $24{ }^{\circ} \mathrm{C}$ overnight by gently stirring. Subsequently, the seeds were dried onto Petri dishes for $24 \mathrm{~h}$ at $24^{\circ} \mathrm{C}$. Re-isolation and identification of the bacterial isolates were also performed from the plant rhizospheres and rhizoplanes (i.e., the external surface of the roots plus the closely adhering soil particles) at the end of the experiment to verify the presence of $P$. fluorescens strains after plant growth following the procedures described above. Another set of M. jalapa seed was used to assess the percentage of germination after coating with $P$. fluorescence strains. Forty seeds were screened for each strain. The percentage of seed germination was evaluated in Petri dishes at room temperature $\left(15-24{ }^{\circ} \mathrm{C}\right)$, when the appearance of the emergent radicle reached about $2 \mathrm{~mm}$ in length using the following formula: $\mathrm{GP}=(\mathrm{SNG} / \mathrm{SNO}) \times 100 \%$, where GP is the germination percentage, $\mathrm{SNG}$ is the number of germinated seeds and SNO is the number of seeds). The experiment was repeated twice.

\subsection{Pot Experiments and Plant Growth Parameters}

Phytoremediation experiments were performed during the summer by filling polyethylene pots (3 1) with the soil samples collected at Santa Maria la Fossa without the spherical, metalloid residues from the smelter. Noncontaminated soil was used as a control. Both coated and non-coated $M$. jalapa seeds were germinated in Petri dishes kept in a controlled room with a 1-h photoperiod and a temperature ranging from $18{ }^{\circ} \mathrm{C}$ to $25^{\circ} \mathrm{C}$. After germination, both the bacteria-coated and noncoated $M$. jalapa seeds were planted according to the soil type on the same day, with one seed per pot. The potted plants were cultivated with open-field conditions. They received a full sun exposure, regular watering and no fertilisation. For each experimental group, $25 \mathrm{M}$. jalapa plants were used. Shoot growth was monitored every 25 days by measuring the shoot length from the culm base to the tip of the longest leaf. The main root length was measured from the root-shoot junction to the tip of the longest root 75 days after sowing. At the end of the experiment, the shoots and roots taken from the nonbioinoculated M. jalapa plants were oven-dried at $70{ }^{\circ} \mathrm{C}$ for $24 \mathrm{~h}$ and then weighed for dry weight determination.

\subsection{Photosynthetic Pigment Content Analysis}

To verify if the smelter-contaminated soil induced alterations in the $M$. jalapa photosynthetic pigments, the leaf content of chlorophyll $\mathrm{a}$, chlorophyll $\mathrm{b}$ and total carotenoids was determined at 25, 50 and 75 days after sowing. Pigments were extracted by grinding $0.25 \mathrm{~g}$ of freshly sampled leaves in $N, N$-dimethylformamide at room temperature in the dark according to Wellburn (1994). Pigment quantification was determined by measuring the absorbance at 480 , 647 and $664 \mathrm{~nm}$ using a spectrophotometer (Jasco V530 UV-VIS Spectrophotometer; Jasco, Tokyo, Japan). The Wellburn equations (1994) were used to calculate the total content of chlorophyll $a$, chlorophyll $b$ and carotenoids.

\subsection{Heavy Metal Concentration Analysis in the M. jalapa Rhizosphere and Leaves}

To determine the metal concentration in the M. jalapa rhizosphere and leaves, chemical analyses were performed upon the removal of the plant from the pot at the mature stage (i.e., the presence of seeds) 75 days after sowing. The M. jalapa plants were gently removed from the pot. Subsequently, the leaves and main root were detached from the stem. The rhizosphere soil (i.e., the soil released from around the roots, including the tiny particles (1-2 $\mathrm{mm}$ ), after gentle shaking) was used for determining the metal content. After isolation was performed to assess the presence of $P$. fluorescens strains in the plant rhizosphere, all single samples were dried in an oven at $75^{\circ} \mathrm{C}$ for $24 \mathrm{~h}$. To evaluate the total $\mathrm{Cd}, \mathrm{Cr}, \mathrm{Cu}, \mathrm{Ni}, \mathrm{Pb}$ and $\mathrm{Zn}$ concentration, the ovendried rhizosphere and leaf samples were ground into a fine powder using an agate pocket (Fritsch Pulverisette type 00.502, Oberstein, Germany), endowed with temperature control and mineralised using a combination of hydrofluoric and nitric acid ( $\mathrm{HF} 50 \% \mathrm{v} / \mathrm{v}: \mathrm{HNO}_{3}$ $65 \% \mathrm{v} / \mathrm{v}=1: 2$ ) in a PYRO Rapid Microwave (Milestone Microwave Laboratory Systems 1200, Shelton, CT, USA). After digestion, the solutions were diluted with deionised water to a final volume of $50 \mathrm{ml}$. The concentration of each element was measured by atomic adsorption spectrometry (SpectrAA 20 Varian, Lake Forest, CA, USA) and quantified using standard solutions (STD Analyticals Carlo Erba, Milano, Italy). The $\mathrm{Cd}, \mathrm{Cr}, \mathrm{Cu}, \mathrm{Pb}$ and $\mathrm{Ni}$ concentrations were measured via graphite furnace AAS, and the $\mathrm{Zn}$ concentration was measured by flame AAS. Accuracy was examined by concurrent analysis of standard reference materials by the Resource Technology Corporation (Laramie, WY, USA); the recovery ranged from $90 \%$ to $100 \%$ 
for each element (Papa et al. 2010; Bartoli et al. 2012). The analyses were performed three times.

\subsection{Evaluation of Heavy Metal Uptake in M. jalapa Leaves}

To evaluate the percentage of heavy metals uptake into $M$. jalapa leaves as a function of the metal accumulation found in the plant rhizosphere at the end of the experiment, the PU percentage was calculated as follows (Doumett et al. 2008):

$\mathrm{PU}(\%)=100 \times \frac{\mathrm{Me}_{\text {leaves }}}{\mathrm{Me}_{\text {rhisosphere }}}$,

where $\mathrm{Me}_{\text {leaves }}$ and $\mathrm{Me}_{\text {rhizosphere }}$ are the heavy metal concentration ( $\mu \mathrm{g} \mathrm{g}^{-1}$ of dry weight) found in $M$. jalapa leaves and rhizosphere at the end of the experiment (75 days after sowing), respectively.

\subsection{Statistical Analysis of Data}

The mean heavy metal concentration and M. jalapa main root lengths are expressed as means \pm standard deviation (SD). Statistical analyses on the heavy metal availability in the plant rhizosphere and leaves and the effectiveness of the $P$. fluorescens strains to increase heavy metal availability and PU were performed using an ANOVA and the least significant difference (LSD) test for mean comparisons with the SPSS software package, version 20.0 (SPSS Inc., Chicago, IL, USA). Differences at $p<0.05$ were considered statistically significant and are indicated with different letters. In addition, since the heavy metal content in the rhizosphere and in the leaf represent multidimensional data sets, we also performed a principal component analysis (PCA). First, we performed a logarithmic data transformation to standardize the data. The correlation among the heavy metal content in the leaves and rhizosphere as obtained from the inoculated and not inoculated $M$. jalapa plants grown in the smelter-contaminated soil, were analysed using Pearson's correlations $(p<0.05$ and $p<0.01)$. PCA was applied to describe the relation between the bacterial strains and the heavy metal content in the rhizosphere and in the leaf, so to identify the principal components which accounted for the majority of the variation within the dataset utilised. The factors were orthogonally rotated, following the "Varimax" method, with Kaiser normalisation that maximizes the sum of the variances of the squared loadings. The analysis was performed by using SPSS software package, version 20.0 (SPSS Inc.).

\section{Results}

\subsection{Soil Characteristics}

The smelter-contaminated soil was found to be highly polluted with various heavy metals (Table 2). In particular, $\mathrm{Cd}, \mathrm{Pb}$ and $\mathrm{Zn}$ highly exceeded the limits set by the Italian law for both type A soils (soils devoted to public gardening and/or private utilisation) and type B soils (soils devoted to commercial/industrial utilisation). The values for $\mathrm{Cr}$ and $\mathrm{Cu}$ were higher for type $\mathrm{A}$ soils, and only the Ni content did not exceed either limit.

\subsection{Identification of Fluorescent Pseudomonads and Re-isolation from Potted Plants}

The isolation of bacteria from the rhizosphere of wild plants grown in smelter-contaminated soil allowed for the recovery of fluorescent colonies on KB medium. For each species, five fluorescent bacterial isolates were purified on NA for their identification. Using LOPAT tests, the isolates were determined to be levan-negative, cytochrome oxidase-positive, potato soft rot-negative, arginine dehydrolase-positive and negative for the hypersensitivity reaction on tobacco leaves (i.e., not phytopathogenic fluorescent pseudomonads). For each plant species, three representative isolates were compared with two $P$. fluorescens reference strains, NCPPB 1801 and 1802 by rep-PCR using ERIC and BOX primer sets. This comparison revealed an identical fingerprint pattern for some fluorescent isolates obtained from the four wild plant species to that from the reference $P$. fluorescens strains. In addition, these isolates yielded the 450-bp band that is specific for Pseudomonas spp., $\mathrm{PSM}_{\mathrm{G}}$. Next, one P. fluorescens strain was chosen for each species for the M. jalapa seed coating experiment, namely CD1 (Cynodon dactylon), AA27 (Artemisia annua), CC45 (Conyza canadensis) and MO49 (Melilotus officinalis). The four P. fluorescens strains were consistently found to be associated with the M. jalapa rhizosphere and rhizoplane at the end of the experiment by taking sub-samples from different parts of the whole root system and re-isolating and further identifying the bacterial isolates. 
3.3 Seed Germination, Plant Growth Parameters and Photosynthetic Pigment Content

The percentage of $M$. jalapa seed germination is reported in Table 3. The germination of M. jalapa from non-coated seeds was higher in the control soil (78 \%) than the contaminated soil (75\%). Bioinoculation with $P$. fluorescens strains significantly increased the germination of M. jalapa seeds in both soils. In fact, the percentage of seed germination was consistently higher than that observed for the non-coated seeds. The cumulative shoot length of the M. jalapa plants is reported in Fig. 2a and b. In general, the length of the plants was higher in the non-contaminated soil than the smelter-contaminated soil: $49.0-63.0$ vs. $45.0-$ $58.0 \mathrm{~cm}$, respectively. Interestingly, in the contaminated soil, all of the P. fluorescens strains induced a significant increase in plant shoot length compared with that of the plants originating from the noncoated seeds. Similar to shoot length, the M. jalapa plants developed longer main roots when they were grown in the control soil (Fig. 3). In the contaminated soil, the seed bioinoculation promoted an increase in root length when compared with the non-coated seeds. However, in this case the increase was not significant. The dry weight of the M. jalapa leaves and roots and the photosynthetic pigment content determined from the non-bioinoculated plants grown in the polluted and control soils are shown in Table 4. It is evident that the high content of heavy metals in the soil induced a decrease in either the leaf dry weight or photosynthetic pigment content during all vegetative phase of the plant. In contrast, the root dry weight increased. No necrotic lesions were observed along the shoots or

Table 3 Mirabilis jalapa seed germination, expressed as percentage and standard deviation, on the smelter-contaminated and control soils

\begin{tabular}{lll}
\hline $\begin{array}{l}\text { Pseudomonas } \\
\text { fluorescens } \text { strain }\end{array}$ & Control soil & $\begin{array}{l}\text { Smelter-contaminated } \\
\text { soil }\end{array}$ \\
\hline CD1 & $81 \pm 1.05 \%^{\mathrm{b}}$ & $92 \pm 1.45 \%{ }^{\mathrm{de}}$ \\
$\mathrm{AA} 27$ & $83 \pm 1.15 \%^{\mathrm{bc}}$ & $76 \pm 1.55 \%^{\mathrm{ab}}$ \\
CC45 & $90 \pm 1.25 \%^{\mathrm{d}}$ & $91 \pm 1.45 \%^{\mathrm{d}}$ \\
MO49 & $85 \pm 2.55 \%^{\mathrm{c}}$ & $84 \pm 2.35 \%^{\mathrm{c}}$ \\
Non-coated seeds & $78 \pm 1.75 \%^{\mathrm{a}}$ & $75 \pm 1.05 \%^{\mathrm{a}}$
\end{tabular}

Different letters indicate statistical significance according to the ANOVA and the LSD test, at $p<0.05$ leaves. However, despite the reduction in the photosynthetic pigment content, the M.jalapa plants yielded seeds at the end of the experiment. The M. jalapa seed bioinoculation with AA27, CC45 and MO49 increased both the root and shoot dry weight in the smeltercontaminated soil (Fig. 4).

\subsection{Heavy Metal Content in the M. jalapa Rhizosphere}

The mean values and corresponding standard deviation of the $\mathrm{Cd}, \mathrm{Cr}, \mathrm{Cu}, \mathrm{Ni}, \mathrm{Pb}$ and $\mathrm{Zn}$ concentrations determined in $M$. jalapa rhizospheres 75 days after sowing in control and smelter-contaminated soils in comparison with that of plants grown from non-coated seeds are shown in Fig. 5. Generally, the accumulation of the heavy metals in the rhizosphere observed in the smelter-contaminated soil was relevant for all six metals assessed in this study either with or without seed bioinoculation. The rhizospheres of plants grown in the contaminated soil and the presence of bacterial strains showed a significant increase in heavy metal accumulation in 13 out of 24 combinations when compared with the non-coated plants. This phenomenon was evident for $\mathrm{Cd}$, for which all four P. fluorescens strains promoted a higher accumulation of this metal compared with $M$. jalapa plants obtained from noncoated seeds. The concentration of this metal in the rhizospheres of bioinoculated plants ranged from 270 to $910 \mu \mathrm{g} \mathrm{g}^{-1}$ of dry weight compared with $200 \mu \mathrm{g} \mathrm{g}^{-1}$ of dry weight for the non-coated plants. In addition, for $\mathrm{Cu}, \mathrm{Ni}, \mathrm{Pb}$ and $\mathrm{Zn}$, some $P$. fluorescens strains incited a higher accumulation. It is noteworthy that seed coating with these $P$. fluorescens strains induced a very significant increase in the mobilisation of $\mathrm{Zn}$ in the $M$. jalapa rhizosphere. P. fluorescens AA27, which was isolated from $A$. annua, induced a significantly higher accumulation in the M. jalapa rhizosphere for $\mathrm{Cd}, \mathrm{Cr}$ and $\mathrm{Cu}$. In addition, $P$. fluorescens MO49, which was isolated from Melilotus officinalis, significantly increased the mobilisation of $\mathrm{Ni}$ and $\mathrm{Zn}$ in the M. jalapa plants grown in polluted soil. In contrast, the heavy metal accumulation in the control soil, with the exception of $\mathrm{Ni}$, did not increase upon seed bionoculation.

\subsection{Evaluation of the Heavy Metal Uptake by $M$. jalapa Leaves}

The analysis of the heavy metal concentration in the $M$. jalapa leaves from plants grown in smelter-contaminated 
Fig. 2 Mean cumulative shoot lengths $(\mathrm{cm})$ of Mirabilis jalapa plants grown on the smeltercontaminated (a) and control (b) soils. The M. jalapa seeds were coated with Pseudomonas fluorescens strains (CD1, AA27, CC45, M 49) or non-coated (control). Different letters indicate statistical significance according to the ANOVA and the LSD test, at $p<0.05$
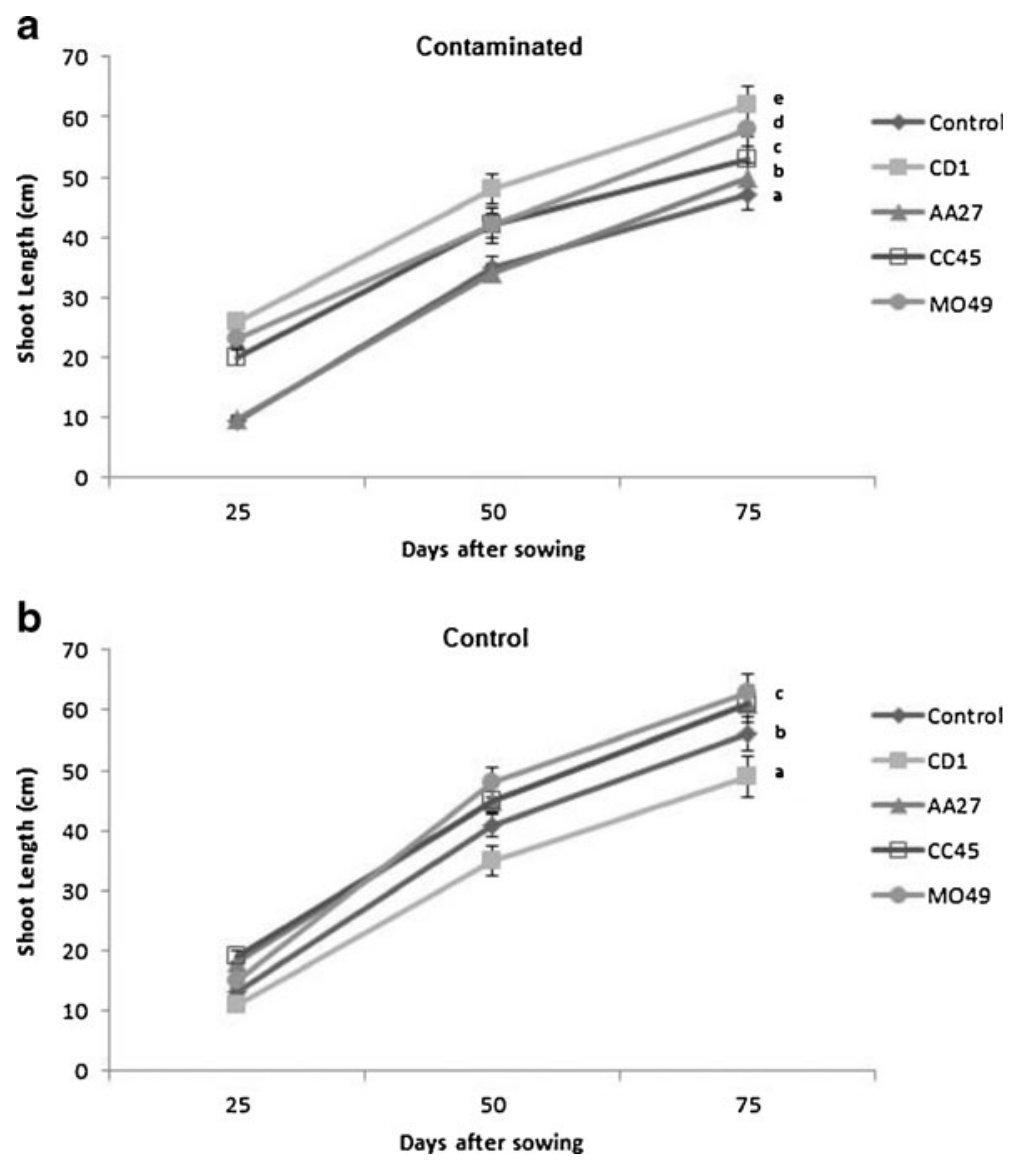

soil from coated and non-coated seeds is shown in Fig. 6. In general, the heavy metal concentration was significantly higher in the leaves of plants grown in smelter-contaminated soil. However, in this case, seed bioinoculation did not incite a significantly higher leaf uptake of heavy metals. In fact, with the exception of $\mathrm{Ni}$, the metal concentration found in plants from non-coated seeds was significantly higher or similar to that found in bioinoculated plants. The PU percentages of $M$. jalapa plants grown in smelter-contaminated soil without seed

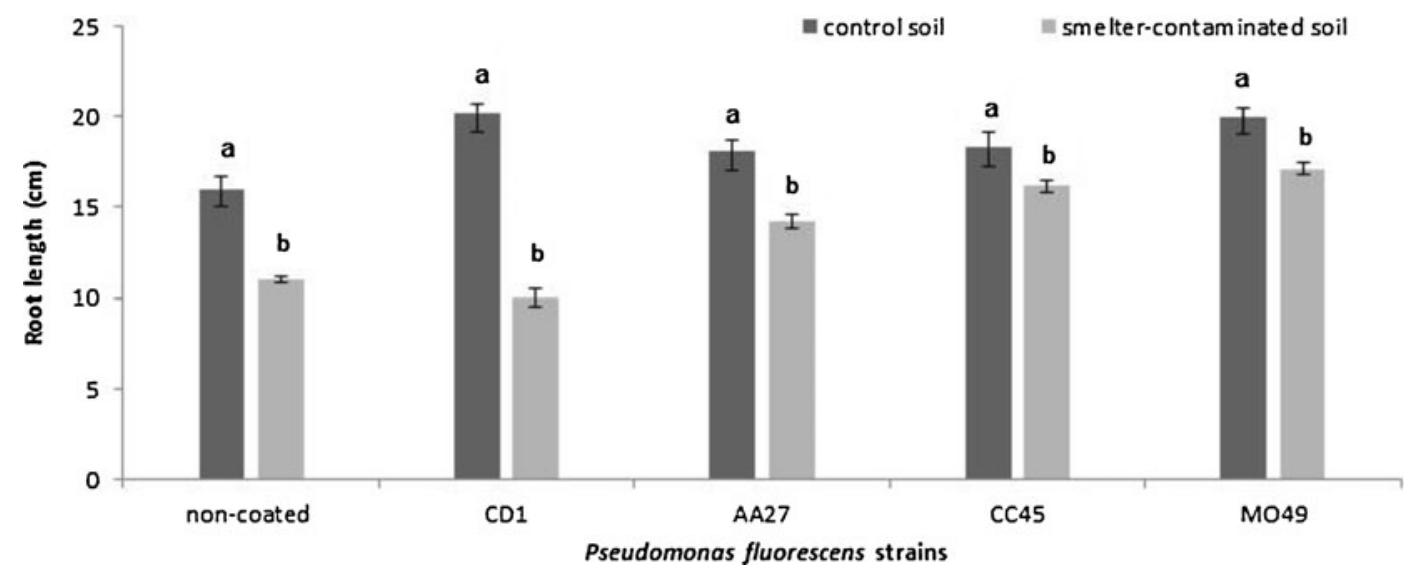

Fig. 3 Mean main root length (cm) in Mirabilis jalapa plants grown in smelter-contaminated and control soils as obtained from seed coated with Pseudomonas fluorescens strains (CD1, AA27, CC45, MO49). Different letters indicate statistical significance according to the ANOVA and the LSD test, at $p<0.05$ 
Table 4 Dry weight of Mirabilis jalapa roots and shoot (g) and leaves pigment content ( $\mathrm{mg} \mathrm{g}^{-1}$ fresh weight) of chlorophyll $a(\mathrm{Chl} a)$, chlorophyll $b(\mathrm{Chl} b)$ and carotenoid
(Car), revealed from plants growing on the smeltercontaminated and control soils, after 25, 50 and 75 days from the sowing

\begin{tabular}{|c|c|c|c|c|c|c|}
\hline \multirow[t]{2}{*}{ Time (days) } & \multirow[t]{2}{*}{ Type of soil } & \multicolumn{2}{|c|}{ Dry weight (g) } & \multirow[t]{2}{*}{ Chl $a$} & \multirow[t]{2}{*}{ Chl $b$} & \multirow[t]{2}{*}{ Car } \\
\hline & & Root & Shoot & & & \\
\hline \multirow[t]{2}{*}{25} & Control & $1.86 \pm 0.18^{\mathrm{a}}$ & $3.21 \pm 0.13^{\mathrm{b}}$ & $0.715 \pm 0.032^{\mathrm{b}}$ & $0.231 \pm 0.043^{\mathrm{b}}$ & $0.159 \pm 0.010^{\mathrm{b}}$ \\
\hline & Contaminated & $2.33 \pm 0.10^{\mathrm{b}}$ & $2.28 \pm 0.06^{\mathrm{a}}$ & $0.419 \pm 0.005^{\mathrm{a}}$ & $0.150 \pm 0.021^{\mathrm{a}}$ & $0.096 \pm 0.009^{\mathrm{a}}$ \\
\hline \multirow[t]{2}{*}{50} & Control & $3.76 \pm 0.12^{\mathrm{a}}$ & $12.6 \pm 0.17^{\mathrm{b}}$ & $1.384 \pm 0.099^{\mathrm{b}}$ & $0.407 \pm 0.067^{\mathrm{b}}$ & $0.330 \pm 0.015^{\mathrm{b}}$ \\
\hline & Contaminated & $5.91 \pm 0.13^{\mathrm{b}}$ & $8.06 \pm 0.09^{\mathrm{a}}$ & $0.819 \pm 0.129^{\mathrm{a}}$ & $0.276 \pm 0.029^{\mathrm{a}}$ & $0.189 \pm 0.008^{\mathrm{a}}$ \\
\hline \multirow[t]{2}{*}{75} & Control & $4.65 \pm 0.16^{\mathrm{a}}$ & $36.92 \pm 0.12^{\mathrm{b}}$ & $1.170 \pm 0.063^{b}$ & $0.335 \pm 0.074^{\mathrm{b}}$ & $0.249 \pm 0.022^{\mathrm{b}}$ \\
\hline & Contaminated & $7.51 \pm 0.08^{\mathrm{b}}$ & $31.69 \pm 0.17^{\mathrm{a}}$ & $0.616 \pm 0.021^{\mathrm{a}}$ & $0.162 \pm 0.013^{\mathrm{a}}$ & $0.105 \pm 0.014^{\mathrm{a}}$ \\
\hline
\end{tabular}

Data are expressed as mean and standard deviation. Different letters indicate statistical significance according to the ANOVA and the LSD test, at $p<0.05$

bioinoculation was high for $\mathrm{Cd}(30.0 \%)$ and $\mathrm{Cu}$ $(12.72 \%)$, whereas a very low uptake was found for $\mathrm{Ni}(2.66 \%), \mathrm{Zn}(2.46 \%), \mathrm{Cr}(1.75 \%)$ and $\mathrm{Pb}(0.73 \%)$. Seed bioinoculation with $P$. fluorescens strains incited a higher uptake in leaves in the case of $\mathrm{Ni}$, with the PU percentages ranging from $2.96 \%$ to $12.46 \%$ compared to $2.81 \%$ found in plants obtained from non-coated seeds. Concerning the other metals, higher PU percentages in comparison with non-coated plants were found only for P. fluorescens $\mathrm{CD} 1$ for $\mathrm{Cr}, \mathrm{Cu}$ and $\mathrm{Zn}$.

\subsection{Principal Component Analysis}

A correlation-based approach, widely applied in environmental studies, was adopted by using Pearson's coefficient for the evaluation of associations between heavy metal content in leaves and rhizosphere of $M$. jalapa grown in the smelter-contaminated soil. It can reveal the relationship between multiple variables for understanding the influencing factors as well as the source(s) of chemical components. The high correlations found between heavy metal content in soil might reflect that their very high concentrations originated from a very similar pollution source (i.e., the smelter) (Tables 5 and 6).

The Pearson matrix also showed some positive and some negative correlations among the heavy metal content in the leaves and rhizosphere in non-inoculated and inoculated plants of $M$. jalapa grown in smeltercontaminated soil (Tables 5 and 6). In fact, concerning the rhizosphere, Cd showed a significant positive correlation with $\mathrm{Cu}(0.775 ; p \leq 0.05), \mathrm{Pb}(0.915 ; p \leq 0.05)$ and $\mathrm{Ni}(0.728 ; p \leq 0.05)$. In addition, $\mathrm{Cr}$ was correlated with
$\mathrm{Pb}(0.679 ; p \leq 0.05)$, whereas $\mathrm{Cu}$ was positively correlated with $\mathrm{Pb}(0.915 ; p \leq 0.05)$ and $\mathrm{Ni}(0.966 ; p \leq 0.05)$. Similarly, $\mathrm{Pb}$ resulted positively correlated with $\mathrm{Ni}$ $(0.863 ; \mathrm{p} \leq 0.05)$. Such data confirm the effectiveness of $P$. fluorescens strains in mobilising heavy metals from soil to the plant rhizosphere. In contrast, in leaves, only $\mathrm{Zn}$ was found to be positively correlated with $\mathrm{Pb}(0.898$; $p \leq 0.05)$ and $\mathrm{Cd}(0.694 ; p \leq 0.05)$. The correlations between heavy metal content found in the rizosphere and in the $M$. jalapa leaves were also analysed (Table 7). There were no significant correlations between $\mathrm{Cd}, \mathrm{Cr}, \mathrm{Pb}$ and $\mathrm{Zn}$. In addition, the correlation coefficients for the content of $\mathrm{Cu}$ and $\mathrm{Ni}$ between the plants and the rizosphere showed to be negatively correlated, at -0.693 and -0.567 , respectively. These data confirmed that despite the mobilisation of heavy metals from the soil to the rhizosphere, their uptake into the leaves resulted quite low.

The Eigenvalues of the covariance matrix showed that the first of the two principal components (PC) accounted for $70.9 \%$ of the total variance in the data set. In particular, PC1 explained $41.8 \%$ of the variance and PC2 explained an additional $29.1 \%$ (Fig. 7). The $\mathrm{Cd}, \mathrm{Cu}, \mathrm{Pb}, \mathrm{Ni}, \mathrm{Zn}$ content in the rhizosphere was significantly positively correlated with $\mathrm{PC} 1$, whereas $\mathrm{Cr}$ was correlated with $\mathrm{PC} 2$. The $\mathrm{Cr}, \mathrm{Cu}$, Ni content in leaves was negatively correlated with $\mathrm{PC} 1$, whereas the content of $\mathrm{Cd}, \mathrm{Pb}$ and $\mathrm{Zn}$ resulted positively correlated with PC2. However, not all heavy metals were distributed on one component, suggesting that all metals might be further controlled by other factors. The PCA plot shows a good separation between inoculated plants with different $P$. fluorescens strains. AA27 and MO49 are located on the positive side of PC1, 

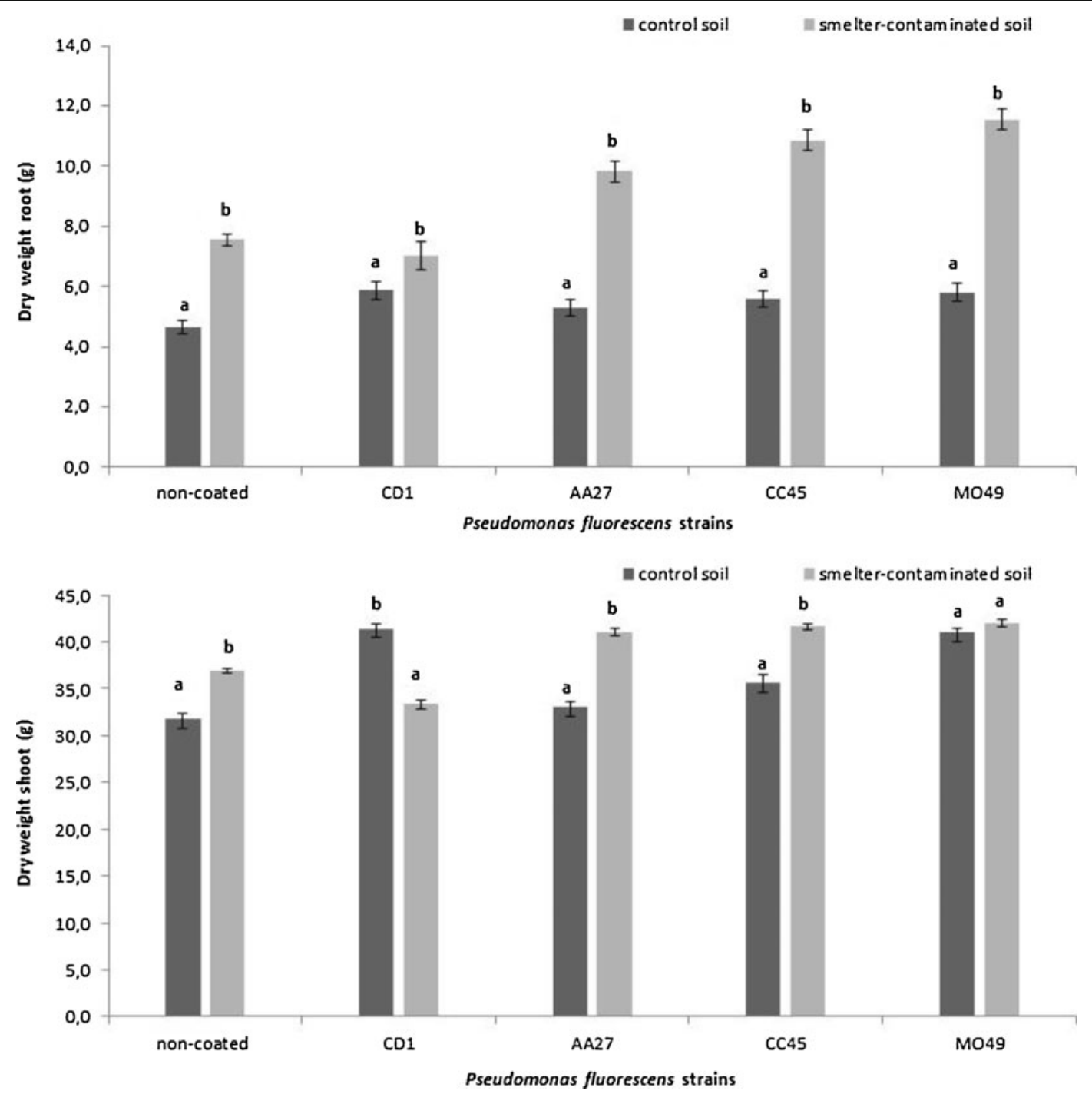

Fig. 4 Mean cumulative dry weight root and shoot (g) of Mirabilis jalapa plants grown on the smelter-contaminated and control soils. The M.jalapa seeds were coated with Pseudomonas

dominated by the presence of metal in the rizosphere, while $\mathrm{CD} 1$ and $\mathrm{CC} 45$ are characterised by the high content of metals in the leaf (Fig. 7).

\section{Discussion}

In this study, P. fluorescens strains were frequently isolated from the rhizospheres of wild plants growing on a soil that was contaminated with illegal waste consisting of smelter residues several years before the sampling and that contained a very high level of heavy fluorescens strains (CD1, AA27, CC45, M 49) or non-coated (control). Different letters indicate statistical significance according to the ANOVA and the LSD test, at $p<0.05$

metals. The four strains utilised in this study were capable of effectively colonising M. jalapa seeds and, subsequently, the rhizospheres for the entire duration of the pot experiment ( 75 days) and, in some cases, of inducing an increase in the heavy metal availability (i.e., the fraction of a chemical that can be taken up or transformed by living organisms) (Semple et al. 2003) of the M. jalapa rhizospheres. In addition, all strains were also recovered from the plant rhizoplane and generally acted as effective PGPR by significantly increasing the plant shoot length, showing their ability to positively interact with M. jalapa. 
smelter-contaminated scil

control soil
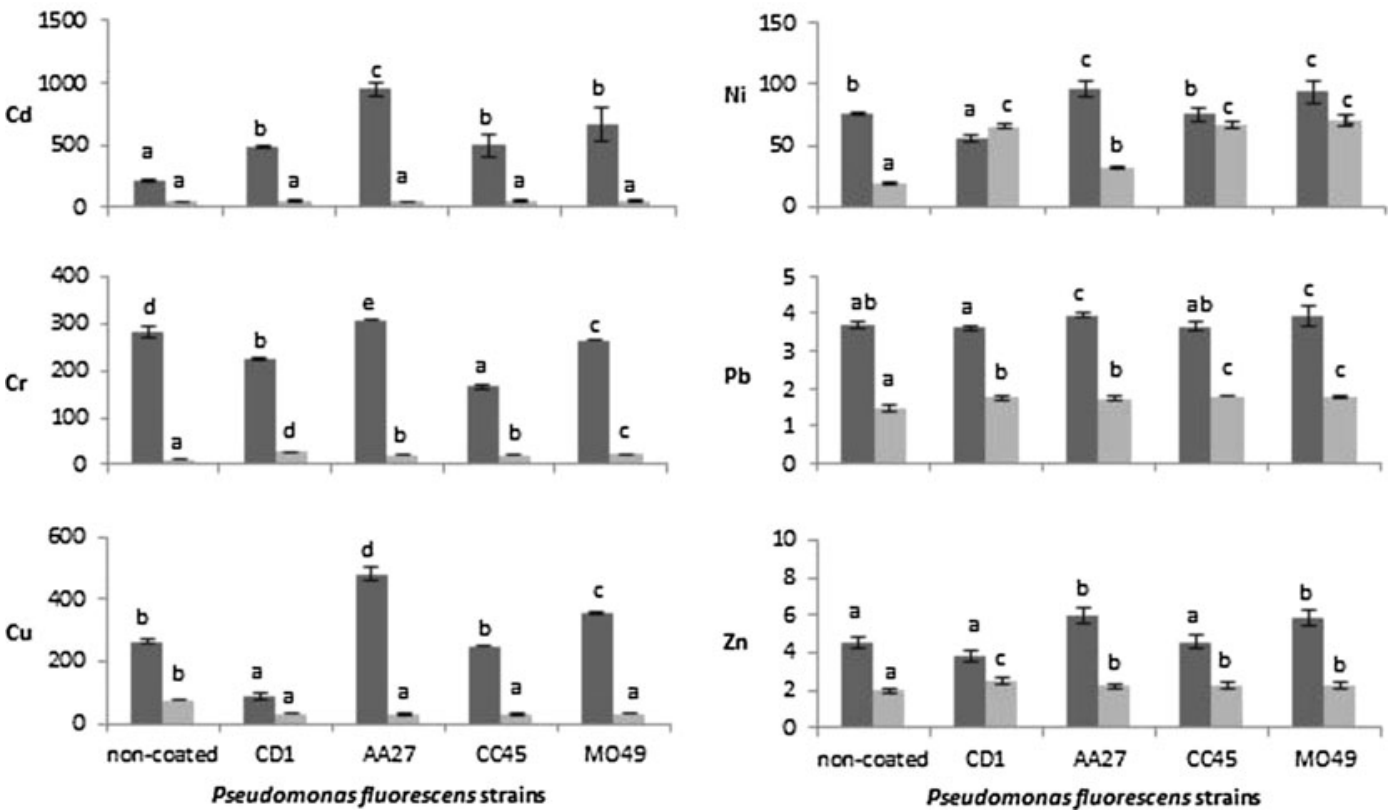

Fig. 5 Mean $(n=3)$ heavy metal content $\left(\mu \mathrm{g} \mathrm{g}{ }^{-1}\right.$ d.w.) and standard deviation in the rhizosphere of Mirabilis jalapa plants grown on the smelter-contaminated and control soils as obtained from M. jalapa seeds coated with Pseudomonas fluorescens strains (CD1, AA27, CC45, MO49) in comparison with $M$.

In particular, our analysis showed that in 13 of 24 bacterium strain/seed combinations, the heavy metal accumulation was significantly higher in $M$. jalapa rhizospheres grown in the contaminated soil and obtained from previously bioinoculated seeds. In addition, two P. fluorescens strains, AA27 and MO49, which were isolated from Artemisia annua and Melilotus officinalis, respectively, significantly incited a higher accumulation of some heavy metals $(\mathrm{Cd}, \mathrm{Cr}$, and $\mathrm{Cu}$ for $\mathrm{AA} 27$; $\mathrm{Ni}$ and $\mathrm{Zn}$ for MO49) in the $M$. jalapa rhizosphere. However, further assessments involving other hyperaccumulator plant species and soils are necessary to confirm and extend their possible practical application in the phytoremediation of soils polluted with heavy metals. It should be stressed that in control soil, in which the concentration of heavy metals was under the law limits, seed bioinoculation did not incite any increase in heavy metal availability for the plant rhizosphere.

P. fluorescens is a versatile Gram-negative bacterium and strains of this species have been isolated from polluted soils and water and show an in vitro capability to tolerate relevant amounts of heavy metals, pesticides,

jalapa plants grown without seed coating. Note that $\mathrm{Pb}$ and $\mathrm{Zn}$ are expressed in a logarithmic scale. Different letters indicate statistical significance according to the ANOVA and the LSD test, at $p<0.05$

herbicides and phenolics (Appanna et al. 1996; Zablotowicz et al. 2001; Shah and Takur 2003; Dell'Amico et al. 2005; Wasi et al. 2008). This bacterium produces siderophores (Dell'Amico et al. 2005), upon stimulation by heavy metals (Van der Lelie et al. 1999), that can effectively increase the solubility of the metals by ligand exchange (Gadd 2004). In addition, natural or engineered strains of $P$. fluorescens have been utilised for the biodegradation of dyes and 2,4dinitrotoluene (Monti et al. 2005; Pandey and Upadhyay 2010). It has been previously shown that suspensions of $P$. fluorescens strains added in experimentally polluted soils enhances the $\mathrm{Pb}$ uptake of Brassica napus (Sheng et al. 2008), whereas B. napus seed inoculation with PGPR, including P. fluorescens, enhances the Cd uptake of the plants grown in a general purpose growth medium (Dell'Amico et al. 2008).

Seed bioinoculation with other PGPR species, either Gram-negative or Gram-positive, such as Acidovorax avenae, Clavibacter xyli, Microbacterium oxydans, $M$. arabinogalactanolyticun, and Rhizobium galega, promoted an increase in Ni availability for the hyperaccumulator Alyssum murale (Abou-Shanab et al. 2006), whereas 

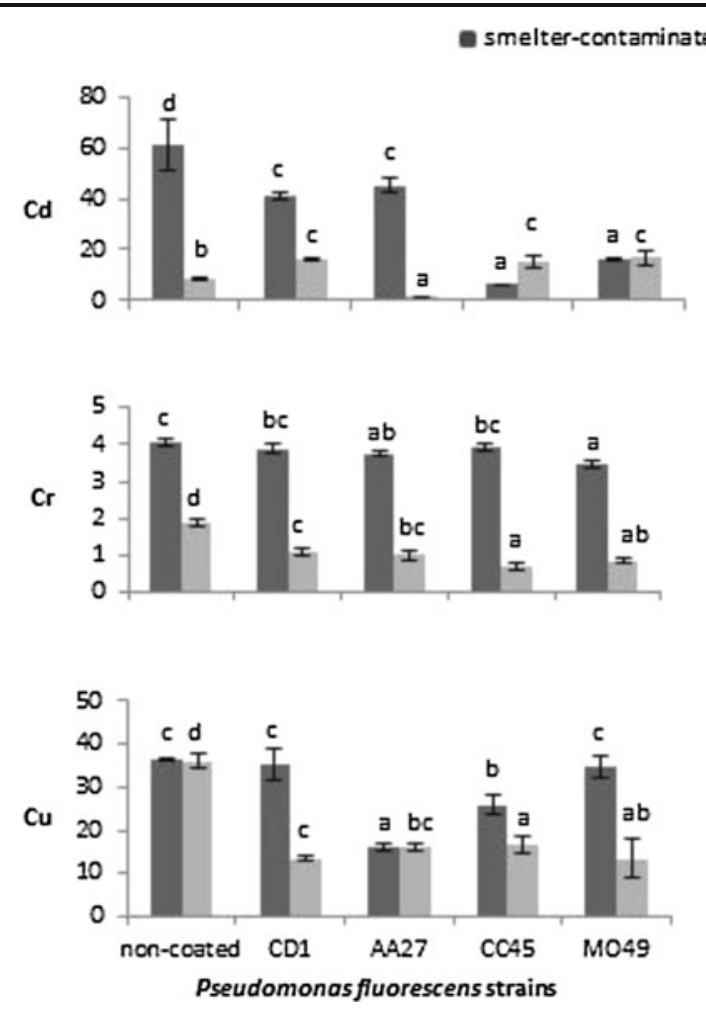

Fig. 6 Mean $(n=3)$ heavy metal content $\left(\mu \mathrm{g} \mathrm{g}{ }^{-1}\right.$ d.w.) and standard deviation in Mirabilis jalapa leaves grown on smeltercontaminated and control soils as obtained from M. jalapa seeds coated with Pseudomonas fluorescens strains (CD1, AA27,

Brassica juncea seed bioinoculation with an Enterobacter sp. strain enhances phytoextraction of $\mathrm{Cr}, \mathrm{Ni}$ and $\mathrm{Zn}$ (Kumar et al. 2008). Moreover, endophytic bacteria (Pseudomonas thivervalensis, Pantoea agglomerans, Ralstonia sp.) isolated from $\mathrm{Cu}$-tolerant plants promote Brassica napus growth and $\mathrm{Cu}$ uptake in a coppercontaminated environment (Zhang et al. 2011).

It should be stressed that, despite their relevant accumulation in the plant rhizosphere, seed bioinoculation with $P$. fluorescens strains did not promote a corresponding higher metal uptake into the M. jalapa leaves.

\section{scil}
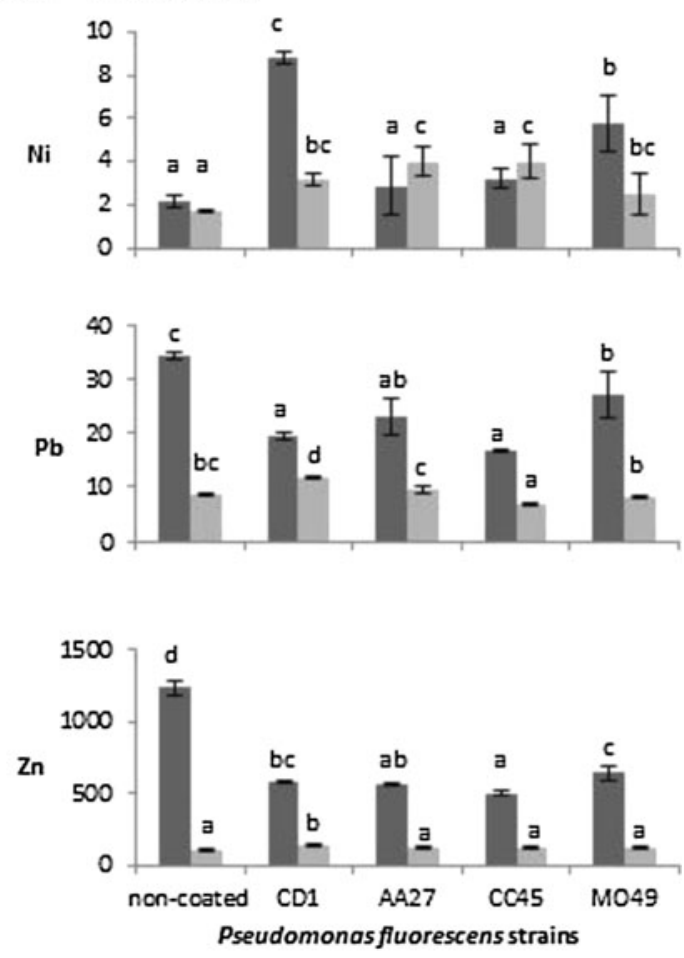

CC45, MO49) in comparison with M. jalapa plants grown without seed coating. Different letters indicate statistical significance according to the ANOVA and the LSD test, at $p<0.05$

Both ANOVA and PCA confirmed this finding. The possibility that the relevant presence of bacteria in the plant root system impedes the metal uptake into the leaves or that the high metal concentration in the roots represents an obstacle for metal absorption and translocation are intriguing concepts that deserves further investigations. However, one P. fluorescens strain, CD1, significantly promoted a higher leaf metal uptake for $\mathrm{Cr}$, $\mathrm{Cu}$ and $\mathrm{Zn}$. Remarkably, this strain was isolated from Cynodon dactylon, a plant species known for its multimetal accumulator properties (Archer and Caldwell
Table 5 Correlation coefficient matrix in Mirabilis jalapa rhizosphere

$r$ rhizosphere

${ }^{*} p \leq 0.05 ; * * p \leq 0.01$

\begin{tabular}{lllllll}
\hline & $\mathrm{Cd}(\mathrm{r})$ & $\mathrm{Cr}(\mathrm{r})$ & $\mathrm{Cu}(\mathrm{r})$ & $\mathrm{Pb}(\mathrm{r})$ & $\mathrm{Ni}(\mathrm{r})$ & $\mathrm{Zn}(\mathrm{r})$ \\
\hline $\mathrm{Cd}(\mathrm{r})$ & 1.000 & & & & \\
$\mathrm{Cr}(\mathrm{r})$ & 0.353 & 1.000 & & & \\
$\mathrm{Cu}(\mathrm{r})$ & $0.775^{* *}$ & $0.613^{*}$ & 1.000 & & \\
$\mathrm{~Pb}(\mathrm{r})$ & $0.915^{* *}$ & $0.679^{* *}$ & $0.915^{* *}$ & 1.000 & \\
$\mathrm{Ni}(\mathrm{r})$ & $0.728^{* *}$ & $0.553^{*}$ & $0.966^{* *}$ & $0.863^{* *}$ & 1.000 & \\
$\mathrm{Zn}(\mathrm{r})$ & 0.362 & 0.246 & 0.371 & 0.403 & $0.575^{*}$ & 1.000 \\
\hline
\end{tabular}


Table 6 Correlation coefficient matrix in Mirabilis jalapa leaves

\begin{tabular}{lcrrrrr}
\hline & $\mathrm{Cd}(1)$ & $\mathrm{Cr}(1)$ & $\mathrm{Cu}(1)$ & $\mathrm{Pb}(1)$ & $\mathrm{Ni}(1)$ & Zn (1) \\
\hline $\mathrm{Cd}(1)$ & 1.000 & & & & \\
$\mathrm{Cr}(1)$ & 0.341 & 1.000 & & & \\
$\mathrm{Cu}(1)$ & 0.104 & -0.107 & 1.000 & & \\
$\mathrm{~Pb}(1)$ & $0.623^{*}$ & -0.067 & 0.402 & 1.000 & & \\
$\mathrm{Ni}(1)$ & -0.197 & -0.124 & 0.460 & -0.420 & 1.000 & \\
$\mathrm{Zn}(1)$ & $0.694^{* *}$ & 0.196 & 0.498 & $0.898^{* *}$ & -0.415 & 1.000 \\
\hline
\end{tabular}

2004). The possibility that the plant species grown in the polluted soil selected bacterial strains able to survive in that soil and to promote heave metal uptake in the leaves cannot be discarded.

This study also revealed a positive role for the $M$. jalapa rhizosphere in increasing the heavy metal accumulation. Plant rhizosphere can either increase or decrease metal availability, and investigations on this specific rhizosphere trait are required also for hyperaccumulator plants (Wenzel 2009). The activity of the plant root system of hyperaccumulator species is capable of solubilising metals/metalloids by means of acidification/alkalinisation, modification of the redox potential, exudation of metal chelants and organic ligands (in particular low molecular weight organic acids and phytosiderophores) that compete with anionic species (e.g., arsenate) for binding sites (Fitz and Wenzel 2002; Wenzel et al. 2003). The mobilising effect of root exudates has been demonstrated in vitro (Mench and Martin 1991) in resin-buffered nutrient solutions and in soil experiments (Shenker et al. 2001). However, increased availability in the rhizosphere is not necessarily associated with increased uptake in the leaves (Wenzel 2009), as has been shown for graminaceous plants regarding Cd (Shenker et al. 2001), the woody hyperaccumulator Paulownia tomentosa regarding $\mathrm{Cd}$ and $\mathrm{Pb}$ (Doumett et al. 2008) and M. jalapa regarding $\mathrm{Pb}$ (Cao et al. 2007). Interestingly, these studies revealed a reduced leaf heavy metal uptake even when chelating agents were added to the polluted soil.

We observed a significant increase in $\mathrm{Cd}, \mathrm{Cr}$ and $\mathrm{Zn}$ concentrations in the rhizospheres of $M$. jalapa plants obtained from non-coated seeds compared with their concentrations in bulk soil. This result revealed a novel trait for this species which has never been challenged in soil polluted with several heavy metals. It should be also stressed that despite a reduction in the photosynthetic pigment content and leaf dry weight for the duration of the experiment, the $M$. jalapa plants yielded seeds at the end of their vegetative cycle. A decrease in chlorophyll content in plant stressed by heavy metals exposure was also been reported for other hyperaccumulators such as Helianthus annuus (Zengin and Munzuroglu 2006) and Brassica juncea (John et al. 2009).

Interestingly, we found a higher root dry weight for plants grown in the polluted soil compared with plants grown in the control soil. Arduini et al. (1995) found a consistent correlation between a high level of $\mathrm{Cu}$ in the culture solution and an increase in root growth and dry weight in Pinus pinea and P. pinaster seedlings. In addition, Younis (2007) observed an increase in root dry weight of Lablab purpureus in presence of high level of $\mathrm{Cu}$. The concentration of this metal in our soil exceeded the low limit by 1.64 -fold, but the effect of single and/or combinations of heavy metals in possibly
Table 7 Correlation coefficient matrix for heavy metal levels in rhizosphere and leaves of Mirabilis jalapa

$r$ rhizosphere, $l$ leaf

${ }^{*} p \leq 0.05 ;{ }^{* *} p \leq 0.01$

\begin{tabular}{lllllll}
\hline & $\mathrm{Cd}(\mathrm{r})$ & $\mathrm{Cr}(\mathrm{r})$ & $\mathrm{Cu}(\mathrm{r})$ & $\mathrm{Pb}(\mathrm{r})$ & $\mathrm{Ni}(\mathrm{r})$ & $\mathrm{Zn}(\mathrm{r})$ \\
\hline $\mathrm{Cd}(\mathrm{l})$ & -0.262 & $0.685^{* *}$ & -0.002 & 0.045 & -0.146 & -0.419 \\
$\mathrm{Cr}(\mathrm{l})$ & -0.310 & -0.131 & -0.259 & -0.307 & -0.382 & $-0.691^{* *}$ \\
$\mathrm{Cu}(\mathrm{l})$ & $-0.797^{* *}$ & -0.174 & $-0.693^{* *}$ & $-0.708^{* *}$ & $-0.538^{*}$ & 0.209 \\
$\mathrm{~Pb}(\mathrm{l})$ & -0.326 & $0.676^{* *}$ & 0.233 & 0.072 & 0.275 & 0.224 \\
$\mathrm{Ni}(1)$ & -0.118 & -0.303 & $-0.642^{* *}$ & -0.324 & $-0.567^{*}$ & 0.184 \\
$\mathrm{Zn} \mathrm{(1)}$ & $-0.645^{* *}$ & 0.416 & -0.079 & -0.286 & -0.078 & -0.152 \\
\hline
\end{tabular}




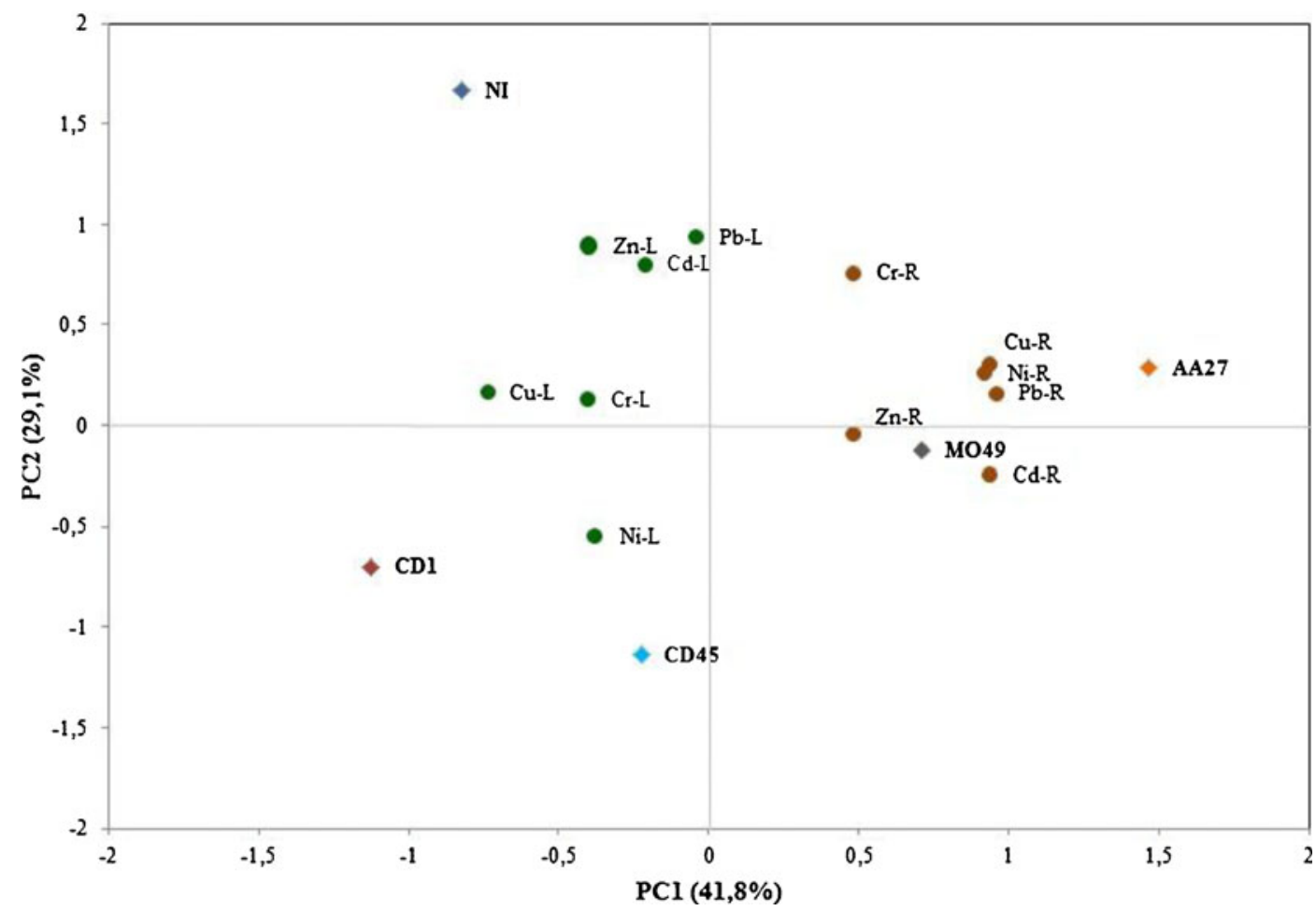

Fig. 7 Biplot of PC1 and PC2 for heavy metals content found in soil (brown circles) and Mirabilis jalapa leaves (green circles). $\mathrm{Cd}, \mathrm{Cr}, \mathrm{Cu}, \mathrm{Ni}, \mathrm{Pb}, \mathrm{Zn}$ are variables used in the principal

inducing a root mass and weight increase in M. jalapa requires further investigations.

In contrast, the metal PU in the leaves of M. jalapa plants that were not bioinoculated was high only for $\mathrm{Cd}$ and $\mathrm{Cu}$; the PU percentages were $30 \%$ and $12.72 \%$, respectively. Although a relevant metal uptake rate is required for phytoextraction and this can be only achieved if the metal in the rhizosphere soil solution is sustained by fast re-supply from the solid phase (Fitz et al. 2003), a low metal uptake rates are also common for hyperaccumulator plants (Shenker et al. 2001).

Thus, this study confirmed and extended recent observations indicating that $M$. jalapa is a Cd hyperaccumulator plant (Zhou and Liu 2006; Yu and Zhou 2009). Actually, this metal was available in the rhizosphere (up to $900 \mathrm{mg} \mathrm{kg}^{-1}$ of rhizosphere dry weight in the case of bioinoculation with AA27) and showed a relatively high PU (30\%) into the leaves. However, using our experimental conditions, we did not meet the $\mathrm{Cd}$ hyperaccumulation criterion of $100 \mathrm{mg} \mathrm{kg}^{-1}$ of shoot dry weight found for Thlaspi caerulescens (Baker et al. component analysis $(P C A)$ for leaves $(L)$ and rhizosphere $(R)$. Pseudomonas fluorescens strains: CD1, AA27, CC45 and MO49. NI non-inoculated plant

2000), and for M. jalapa fertilised with phosphorous (Yu and Zhou 2009). The maximum concentration of Cd we found was $60 \mathrm{mg} \mathrm{kg}^{-1}$ in the M. jalapa leaves. We also confirmed the findings highlighted by Sun et al. (2011) that M. jalapa is able to uptake $\mathrm{Cd}$ and $\mathrm{Cu}$; in fact, we found a PU of $12.72 \%$ for $\mathrm{Cu}$.

In agreement with Cao et al. (2007), we observed the ability of $M$. jalapa to accumulate $\mathrm{Pb}$ in the rhizosphere, even though the leaves uptake for this metal was the lowest $(0.73 \%)$. This finding is different from the data published by Kambhampati and Williams (2001), which revealed an effective and increasing $\mathrm{Pb}$ uptake from the M. jalapa root to the shoot, but this occurred in the presence of increasing doses of EDTA as a chelating agent in the growth medium.

Studies are required to determine the presence of specific rhizosphere traits with respect to metal mobilisation in hyperaccumulator plants in terms of metal mobilisation are required (Wenzel 2009; de Bashan et al. 2012). Unfortunately, nothing is known about the mechanisms by which M. jalapa root and root exudates interact with heavy metals to possibly 
enhance their solubility in the rhizosphere through the release of siderophores or low molecular organic acids (Cakmak et al. 1996). Studies on the relationships between that plant root system with heavy metals content in the soil could also explain why this species accumulates more weight in its roots when grown in polluted soil compared with normal soil. Finally, this study also confirms that for an effective phytoextraction assisted with PGPR, a preliminary selection of the most suited bacterial strains is necessary according to the socalled "rhizo direct strain selection" (Thompson et al. 2005).

\section{Conclusions}

Our study showed that $P$. fluorescens was consistently isolated from the rhizospheres of wild plants growing on a soil that was highly polluted with many heavy metals. Furthermore, when used as seed bioinoculant, it colonised M. jalapa seeds, rhizospheres and rhizoplanse during our 75-day pot experiment, enhancing the availability of heavy metals in the rhizosphere in some cases, thus demonstrating its ability to inhabit highly polluted soils. In particular, two strains, AA27 and MO49, induced a significantly higher accumulation for some of the analysed heavy metals $(\mathrm{Cd}, \mathrm{Cr}$, and $\mathrm{Cu}$ for AA27; $\mathrm{Ni}$ and $\mathrm{Zn}$ for MO49) in the M. jalapa rhizosphere. We also pointed out a novel trait of $M$. jalapa as being capable of growing and producing seeds in a soil polluted with many heavy metals. We confirmed that this species was able to uptake $\mathrm{Cd}$ and $\mathrm{Cu}$ without seed bioinoculation, with PU percentages of $30 \%$ and $12.72 \%$, respectively. Within this context, we also found that upon bioinoculation, the relationships between the metal accumulation in the rhizosphere and PU are not always related to the metal content found in the rhizosphere. In fact, despite the relevant accumulation of heavy metals in the plant rhizosphere, the metal uptake into the leaves was low. However, one P. fluorescnes strain, which was isolated from the multi-metal accumulator Cynodon dactylon, significantly promoted the $M$. jalapa leaf uptake for $\mathrm{Cr}, \mathrm{Cu}$ and $\mathrm{Zn}$. Further studies are required to investigate the mechanism by which $M$. jalapa interacts with heavy metals in the rhizosphere and the mechanism that regulates the transport of the metal from the rhizosphere to the roots and leaves.
Acknowledgment This research was supported by a multitask co-operation grant between the Consiglio per la Ricerca e Sperimentazione in Agricoltura and Seconda Università degli Studi di Napoli, Caserta.

\section{References}

Abou-Shanab, R. A. I., Angle, J. S., \& Chaney, R. L. (2006). Bacterial inoculants affecting nickel uptake by Alyssum murale from low, moderate and high Ni soils. Soil Biology and Biochemistry, 38, 2882-2889.

Angle, J. S., Gagliardi, J. V., McIntosh, M. S., \& Levin, M. A. (1996). Enumeration and expression of bacterial counts in the rhizosphere. In G. Stotzky \& J. M. Bollag (Eds.), Soil biochemistry, Vol. 9 (pp. 233-251). New York: Marcel Dekker.

Appanna, V. D., Gazso, L. G., \& Pierre, M. S. (1996). Multiplemetal tolerance in Pseudomonas fluorescens and its biotechnological significance. Journal of Biotechnology, 52, 75-80.

Archer, M. J. G., \& Caldwell, R. A. (2004). Response of six Australian plant species to heavy metal contamination at an abandoned mine site. Water, Air, and Soil Pollution, 157, $257-267$.

Arduini, I., Douglas, L., Godbold, D. L., \& Antonio, O. (1995). Influence of copper on root growth and morphology of Pinus pinea L. and Pinus pinaster Ait. seedlings. Tree Physiology, 15, 411-415.

Baker, A. J. M., Mc Grath, S. P., Reeves, R. D., \& Smith, J. A. C. (2000). Metal hyperaccumulator plants: A review of the ecology and physiology of a biochemical resource for phytoremediation of metal polluted soils. In N. Terry \& G. Bañuelos (Eds.), Phytoremediation of contaminated soil and water (pp. 85-107). Boca Raton: Lewis Publishers.

Bartoli, G., Papa, S., Sagnella, E., \& Fioretto, A. (2012). Heavy metal content in sediments along the Calore river: relationships with physical-chemical characteristics. Journal of Environmental Management, 95, 9-14.

Cakmak, I., Sari, N., Marschner, H., Ekiz, H., \& Kalayci, M. (1996). Phytosiderophore release in bread and durum wheat genotypes differing in zinc efficiency. Plant and Soil, 180, 183-189.

Cao, A., Carucci, A., Lai, T., La Colla, P., \& Tamburini, E. (2007). Effect of biodegradable chelating agents on heavy metals phytoextraction with Mirabilis jalapa and on its associated bacteria. European Journal of Soil Biology, 43, 200-206.

De Bashan, L. E., Hernandez, J.-P., \& Bashan, Y. (2012). The potential contribution of plant growth-promoting bacteria to reduce environmental degradation. A comprehensive evaluation. Applied Soil Ecology, 61, 171-189.

Dell'Amico, E., Cavalca, L., \& Andreoni, V. (2005). Analysis of bacterial communities in perennial Graminaceae from polluted water meadow soil, and screening of metal-resistant, potentially plant growth-promoting bacteria. FEMS Microbiology Ecology, 52, 153-162.

Dell'Amico, E., Cavalca, L., \& Andreoni, V. (2008). Improvement of Brassica napus growth under cadmium stress by 
cadmium-resistant rhizobacteria. Soil Biology and Biochemistry, 40, 74-84.

Doumett, S., Lamperi, L., Checchini, L., Azzarello, E., Mugnai, S., Mancuso, S., Petruzzelli, G., \& Del Bubba, M. (2008). Heavy metal distribution between contaminated soil and Paulownia tomentosa, in a pilot-scale assisted phytoremediation study: influence of different complexing agents. Chemosphere, 72, 1481-1490.

Dzantor, E. K. (2007). Phytoremediation: the state of rhizosphere "engineering" for accelerated rhizodegradation of xenobiotic contaminants. Journal of Chemical Technology and Biotechnology, 82, 228-232.

Ferrante, P., \& Scortichini, M. (2009). Identification of Pseudomonas syringae pv. actinidiae as causal agent of bacterial canker of yellow kiwifruit (Actinidia chinensis Planchon) in central Italy. Journal of Phytopathology, 157, 768-770.

Fitz, W. J., \& Wenzel, W. W. (2002). Arsenic transformations in the soil-rhizosphere-plant system: fundamentals and potential application to phytoremediation. Journal of Biotechnology, 99, 259-278.

Fitz, W. J., Wenzel, W. W., Zhang, H., Nurmi, J., Stipek, K., Fiscerova, Z., Schweiger, P., Kollenspeger, G., Mal, Q., \& Stingeder, G. (2003). Rhizosphere characteristics of the arsenic hyperaccumulator Pteris vittata L. and monitoring of phytoremoval efficiency. Environmental Science and Technology, 37, 5008-5014.

Gadd, G. M. (2004). Microbial influence on metal mobility and application to bioremediation. Geoderma, 122, 109-119.

Glick, B. R. (2010). Using soil bacteria to facilitate phytoremediation. Biotechnology Advances, 28, 367-374.

John, R., Ahmadb, P., Gadgila, K., \& Sharmab, S. (2009). Heavy metal toxicity: effect on plant growth, biochemical parameters and metal accumulation by Brassica juncea L. International Journal of Plant Production, 3, 65-76.

Johnsen, K., Enger, O., Jacobens, C. S., Thirupo, L., \& Torsvik, V. (1999). Quantitative selective PCR of $16 \mathrm{~S}$ ribosomal DNA correlates well with selective agar plating in describing population dynamics of indigenous Pseudomonas spp. in soil hot spots. Applied and Environmental Microbiology, $65,1786-1789$.

Kambhampati, M.S., \& Williams, L. (2001). Phytoremediation of lead contaminated soils using Mirabilis jalapa. In: A. Leeson, E.A. Foote, M.K. Banks, \& V.S. Magar (Eds.), Phytoremediation, wetlands and sediments, Proceedings of the sixth international in situ and on site bioremediation symposium (pp. 145-150). San Diego, CA, USA: Battelle Press.

Khan, M. S., Zaidi, A., Wani, P. A., \& Oves, M. (2009). Role of plant growth promoting rhizobacteria in the remediation of metal contaminated soils. Environmental Chemistry Letters, 7, 1-19.

King, E. O., Ward, M. K., \& Raney, D. E. (1954). Two simple media for the demonstration of pioverdin and fluorescein. The Journal of Laboratory and Clinical Medicine, 44, 301-307.

Kumar, K. V., Singh, N., Behl, H. M., \& Srivastava, S. (2008). Influence of plant growth promoting bacteria and its mutant on heavy metal toxicity in Brassica juncea grown in fly ash amended soil. Chemosphere, 72, 678-683.

Lebeau, T., Braud, A., \& Jezequel, K. (2008). Performance of bioaugmentation-assisted phytoextraction applied to metal contaminated soils: a review. Environmental Pollution, 153, 497-522.
Lelliott, R. A., \& Stead, D. E. (1987). Methods for the diagnosis of bacterial diseases of plants. Oxford: Blackwell Scientific Publications.

Louws, F. J., Fulbright, D. W., Stephens, C. T., \& De Bruijn, F. J. (1994). Specific genomic fingerprints of phytopathogenic Xanthomonas and Pseudomonas pathovars and strains generated with repetitive sequences and PCR. Applied and Environmental Microbiology, 60, 2286-2295.

Mc Grath, S. P., Zhao, F. J., \& Lombi, E. (2001). Plant and rhizosphere process involved in phytoremediation of metal-contaminated soils. Plant and Soil, 232, 207-214.

Mench, M., \& Martin, E. (1991). Mobilization of cadmium and other metals from two soils by root exudates of Zea mays L., Nicotiana tabacum L. and Nicotiana rustica L. Plant and Soil, 132, 187-196.

Ministry of Agricultural, Food and Forestry Policies (1999). Metodi ufficiali di analisi chimica del suolo. Decreto Ministeriale del 13 settembre 1999. Official Journal Supplement no. 284, 21/10/1999.

Monti, M. R., Smania, A. M., Fabro, G., Alvarez, M. E., \& Argaraña, C. E. (2005). Engineering Pseudomonas fluorescens for biodegradation of 2,4-dinitrotoluene. Applied and Environmental Microbiology, 71, 8864-8872.

Pandey, B. V., \& Upadhyay, R. S. (2010). Pseudomonas fluorescens can be used for bioremediation of textile effluent direct orange. Tropical Ecology, 51, 397-403.

Papa, S., Bartoli, G., Pellegrino, A., \& Fioretto, A. (2010). Microbial activities and trace element contents in an urban soil. Environmental Monitoring and Assessment, 165, 193203.

Pignatti, S. (1982). Flora d'Italia, Vol. 1-3. Bologna: Edagricole.

Scortichini, M., Marchesi, U., \& Di Prospero, P. (2002). Genetic relatedness among Pseudomonas avellanae, $P$. syringae $\mathrm{pv}$. theae and P. s. pv. actinidiae, and their identification. European Journal of Plant Pathology, 108, 269-278.

Scortichini, M., Marchesi, U., Rossi, M. P., Angelucci, L., \& Dettori, M. T. (2000). Rapid identification of Pseudomonas avellanae field isolates, causing hazelnut decline in central Italy, by repetitive PCR genomic fingerprinting. Journal of Phytopathology, 148, 153-159.

Semple, K. T., Morriss, A. W. J., \& Paton, G. I. (2003). Bioavailability of hydrophobic organic contaminants in soils: fundamental concepts and techniques for analysis. European Journal of Soil Science, 54, 809-818.

Shah, S., \& Thakur, I. S. (2003). Enzymatic dehalogenation of pentachlorophenol by Pseudomonas fluorescens of the microbial community from tannery effluent. Current Microbiology, 47, 65-70.

Sheng, X. F., Xia, J. J., Jiang, C. Y., He, L. Y., \& Qian, M. (2008). Characterization of heavy metal-resistant endophytic bacteria from rape (Brassica napus) roots and their potential in promoting the growth and lead accumulation of rape. Environmental Pollution, 156, 1164-1170.

Shenker, M., Fan, T. W.-M., \& Crowley, D. E. (2001). Phytosiderophores influence on cadmium mobilization and uptake by wheat and barley plants. Journal of Environmental Quality, 30, 2091-2098.

Sriprang, R., \& Murooka, Y. (2007). Accumulation and detoxification of metals by plants and microbes. In S. N. Singh \& R. D. Tripathi (Eds.), Environmental bioremediation technologies (pp. 77-100). Berlin: Springer-Verlag. 
Sun, Y. B., Sun, G. H., Zhou, Q. Y., Xu, Y. M., Wang, L., Liang, X. F., Sun, Y., \& Qing, X. (2011). Induced-phytoextraction of heavy metals from contaminated soil irrigated by industrial wastewater with Marvel of Peru (Mirabilis jalapa L.). Plant Soil and Environment, 57, 364-371.

Thompson, I. P., Van der Gast, C. J., Ciric, L., \& Singer, A. C. (2005). Bioaugmentation for bioremediation: the challenge of strain selection. Environmental Microbiology, 7, 909915.

Van der Lelie, D., Corbisier, P., Diels, L., Gilis, A., Lodewyckx, C., Mergeay, M., Taghavi, S., Spelmans, N., \& Vangronsveld, J. (1999). The role of bacteria in the phytoremediation of heavy metals. In N. Terry \& E. Bañuelos (Eds.), Phytoremediation of contaminated soil and water (pp. 265-281). Boca Raton: Lewis Publishers.

Van Elsas, J. D., Van Overbeek, L. S., Feldmann, A. M., Dullemans, A. M., \& De Leeuw, O. (2006). Survival of genetically engineered Pseudomonas fluorescens in soil in competition with the parent strain. FEMS Microbiology Letters, 85, 53-64.

Wasi, S., Jeelani, G., \& Ahmad, M. (2008). Biochemical characterization of a multiple heavy metal, pesticides and phenol resistant Pseudomonas fluorescens strain. Chemosphere, 71, $1348-1355$.

Wasi, S., Tabrez, S., \& Ahmad, M. (2010). Suitability of immobilized Pseudomonas fluorescens SM1 strain for remediation of phenols, heavy metals, and pesticides from water. Water, Air, and Soil Pollution, 220, 89-99.

Wellburn, A. R. (1994). The spectral determination of chlorophylls $\mathrm{A}$ and $\mathrm{B}$, as well as total carotenoids, using various solvents with spectrophotometers of different resolution. Journal of Plant Physiology, 144, 307-313.

Wenzel, W. W., Bunkowski, M., Puschenreiter, M., \& Horak, O. (2003). Rhizosphere characteristics of indigenously growing nickel hyperaccumulator and tolerant plants on serpentine soil. Environmental Pollution, 123, 131-138.

Wenzel, W. W. (2009). Rhizosphere processes and management in plant-assisted bioremediation (phytoremediation) of soils. Plant and Soil, 32, 385-408.

Younis, M. (2007). Response of Lablab purpureus-Rhizobium symbiosis to heavy metals in pot and field experiments. World Journal of Agricultural Science, 3, 111-122.

Yu, Z., \& Zhou, Q. (2009). Growth responses and cadmium accumulation of Mirabilis jalapa L. under interaction between cadmium and phosphorus. Journal of Hazardous Materials, 167, 38-43.

Zablotowicz, R.M., Hoagland, R.E., Lee, H., Alber, T., Trevors, J.T., Hall, J.C. et al. (2001). Transformation of nitroaromatic pesticides and related xenobiotics by microorganisms and plants. In J.C. Hall,. R.E. Hoagland, \& R.M. Zablotowicz (Eds), Pesticide biotransformation in plants and microorganisms: similarities and divergences. ACS Symposium Series 777. Washington, DC, American Chemical Society.

Zengin, F. K., \& Munzuroglu, O. (2006). Toxic effects of cadmium $\left(\mathrm{Cd}^{++}\right)$on metabolism of sunflower (Helianthus annuus L.) seedlings. Acta Agriculturae Scandinavica. Sect. B. Plant Soil Science, 56, 224-229.

Zhang, Y., He, L., Chen, Z., Wang, Q., Qian, M., \& Sheng, X. (2011). Characterization of ACC deaminase-producing endophytic bacteria isolated from copper-tolerant plants and their potential in promoting the growth and copper accumulation of Brassica napus. Chemosphere, 83, 57-62.

Zhou, Q.X., \& Liu, J.N. (2006). A new method to remediate Cdcontamination soil by Mirabilis jalapa L., China Patent No. 200610046244.9.

Zhuang, X., Chen, J., Shim, H., \& Bai, Z. (2007). New advances in plant growth-promoting rhizobacteria for bioremediation. Environmental International, 33, 406-413. 